\title{
Effects of Egg Shell Temperature and Incubator Ventilation Programme on Incubation Results of Broiler Breeders
}

\author{
${\text { Nezih } \text { Okur }^{1 *}, \text { Sabri Arda Eratalar }}^{1}$, Hasan Eleroğlu ${ }^{2}$ \\ ${ }^{1}$ Poultry Scince Department, Agriculture and Natural Science Faculty, Abant Izzet Baysal University, 14280 Bolu, Turkey \\ ${ }^{2}$ Sarkisla Asik Veysel Vocational High School, Cumhuriyet University, 58146 Sivas, Turkey
}

\section{A R T I C L E I N F O}

Research Articles

Received 06 November 2017

Accepted 05 April 2018

Keywords:

Broiler

Incubation

Egg shell temperature

Egg weight

Hatchability of fertile eggs

"Corresponding Author:

E-mail: nezihokur@ibu.edu.tr

\section{A B S T R A C T}

The impacts of egg weight (EW), egg shell temperature (EST), egg position in the incubator (EP) and incubator ventilation program (IVP) on embryonic mortality (EM) and hatchability of fertile eggs (HFE) of broiler breeders were investigated in this study. EW was determined total 1920 hatching eggs which were obtained from middle aged (31 weeks) Ross 308 broiler breeders. These eggs were classified according to weight as heavy $(65.52 \pm 0.08 \mathrm{~g})$, medium $(61.47 \pm 0.04 \mathrm{~g})$ and light $(57.56 \pm 0.08 \mathrm{~g})$ then were randomly set in trolleys of four identical incubators sorted as near the heather side - door side, humidifier side - opposite side and top - middle - bottom. In two incubators $37.78^{\circ} \mathrm{C}\left(100.0^{\circ} \mathrm{F}\right) \mathrm{EST}$ and $38.06^{\circ} \mathrm{C}\left(100.5^{\circ} \mathrm{F}\right)$ EST were provided in the other two. Similarly, two machines were operated on classic IVP system and the other two were operated on new IVP system organised specially for this project during first 10 days of incubation. At the end of the hatching period, data including EM and HFE data were examined in eggs with different EST, EW and EP. It was found that EW and EST were affected to EM and HFE. Lower last stage + pipped but unhatched embryo rates and accordingly higher HFE were determined in eggs with $37.78^{\circ} \mathrm{C}\left(100.0^{\circ} \mathrm{F}\right) \mathrm{EST}$ and light. However, differences between IVP and EP data were not significant.

\section{Yumurta Kabuk Sıcaklığı ile Kuluçka Makinesi Havalandırma Programının Etçi Damızlıklarda Kuluçka Sonuçlarına Etkisi}

\section{A K A L E B İ L G İ S İ}

\section{AraştırmaMakalesi}

Geliş 06 Kasım 2017

Kabul 05 Nisan 2018

Anahtar Kelimeler:

Etlik piliç

Kuluçka

Yumurta kabuk sıcaklığı

Yumurta ağırlığı

Çıkış gücü

"Sorumlu Yazar:

E-mail: nezihokur@ibu.edu.tr

\section{Ö Z E T}

$\mathrm{Bu}$ araştırmada, kuluçkalık etçi damızlık yumurtalarında yumurta ağırlı̆̆ının (YA), yumurta kabuğu sıcaklığının (YKS), kuluçka makinesi havalandırma programının (KMHP) ve yumurtaların makine içerisindeki pozisyonunun (YP) embriyo ölümlerine (EÖ) ve çıkış gücüne (ÇG) etkisi incelenmiştir. Araştırmada, orta yaşlı (31 hafta) ROSS 308 etlik damızlıklardan elde edilen toplam 1920 yumurtanın ağırlıkları belirlenmiştir. Bu yumurtalar ağırlıklarına göre ağır $(65,55 \pm 0,08 \mathrm{~g})$, orta $(61,47 \pm 0,04 \mathrm{~g})$ ve hafif $(57,56 \pm 0,08 \mathrm{~g})$ olarak tasnif edildikten sonra, 4 kuluçka makinesinde bulunan tepsilere 1sıtıc1-kapı, nemlendirici-duvar ve üst-orta-alt şeklinde rastgele yerleştirilerek farklı pozisyonlarda olacak şekilde rastgele yerleştirilerek basılmıştır. Kuluçka döneminde iki makinede $37,78^{\circ} \mathrm{C}$, iki makinede ise $38,06^{\circ} \mathrm{C}$ YKS uygulanmıştır. Benzer şekilde kuluçkanın ilk 10 gününde makinelerden 2 tanesi klasik, 2 tanesi yeni olarak adlandırılan havalandırma programına göre çalıştırılmıştır. Çıkım dönemi sonunda yumurtalardaki EÖ ve ÇG verileri incelenmiştir. YA ve YKS değerlerinin embriyo ölümlerini ve çıkış gücünü etkilediği bulunmuştur. $37,78^{\circ} \mathrm{C}\left(100,0^{\circ} \mathrm{F}\right)$ YKS uygulanan ve hafif olan yumurtalarda daha düşük son dönem+kabuk altı embriyo ölümleri ve buna bağlı olarak daha yüksek ÇG elde edilmiştir. Buna karşılık KMHP ve YP açısından muamele gruplarında elde edilen EÖ ve ÇG verileri arasında önemli bir fark bulunmamıştır. 


\section{Introduction}

Incubation performance is based on genetics, flock age, maintenance and feeding conditions of breeders and can be well altered by diseases, egg weight (EW), incubator temperature, humidity, carbon dioxide $\left(\mathrm{CO}_{2}\right)$ and oxygen $\left(\mathrm{O}_{2}\right)$ levels, (Onagbesan et al., 2008; Meijerhoff 2009; Elibol and Turkoglu, 2014; Turkoglu and Sarica, 2014) and is determined by economic factors like hatchability of fertile eggs (HFE) and hatchability $(\mathrm{H})$.

EW is an important criterion about both incubation and post hatch performance. It has been stated that when EW increases $\mathrm{H}$ decreases (Huwaida et al., 2015) and this is mostly caused by both early (Rosa et al., 2002; Abiola et al., 2008) and late stage (Elibol and Brake, 2008) embryonic deaths. It is advised by the authors that machine temperatures should be decreased at the second stage of incubation for heavy hatching eggs.

Chicken embryos are ectothermic meaning that they cannot balance their body temperatures (Piestun et al., 2008; Walter and Seebacher, 2009) resulting in incubation temperature to be one of the most important criteria about performance (Lourens et al., 2005). The total metabolic heat production of the eggs placed in the incubator and as a result, the temperature in the incubator is increasing in parallel with the embryonic development, egg size and fertility rate (French, 1997). For this reason, it is necessary to understand as much as possible the effects of the most suitable temperature in the incubation period and the effects of exposure to different temperatures of the eggs should be understood for the best performance (Hulet et al., 2007; Shim and Pesti 2011). The temperatures reported in these studies are the machine temperature but the main consideration is the internal temperature of the embryo (French, 2009) and it is reported (Meijerhof, 2009) that the best indicator of this is the egg shell temperature (EST). The egg shell temperature (EST) for broiler hatching eggs are advised to be between $37-38^{\circ} \mathrm{C}$ (Decuypere et al., 2001; Lourens et al., 2005; Joseph et al., 2006; Hulet et al., 2007; Saito and Kita, 2011) and the highest first week live weight is told to have been obtained from $37.78^{\circ} \mathrm{C}$ EST (Lourens et al., 2005; Joseph et al., 2006) was expressed.

Depending on the position of the egg in the incubator (EP), the circulating air velocity in the incubator, flock age, egg weight (EW) and embryo age, difference between the EST and the circulating air temperature is told to be varying from $0.4^{\circ} \mathrm{C}$ to $4.0^{\circ} \mathrm{C}$ (Lourens et al., 2005; Joseph et al., 2006; Elibol and Brake 2008). Last stage embryo deaths are told to be increasing when heavy eggs are set to the far side from the circulating fan and thus HFE is told to be decreasing. This situation is told probably to be caused by the descention of the air circulation velocity far away from the incubator fan and also heavier eggs' being more susceptible to the changing air velocity (Elibol and Brake 2008). This is told to be because of the efficiency of heat transfer in the incubator and by a uniform air circulation this could be overcame (French 1997).

During incubation the $\mathrm{CO}_{2}$ and $\mathrm{O}_{2}$ levels in the incubator are told to be very important for embryonic development and can influence the performance of incubation and also post hatch performance has been reported (Decuypere et al., 2001; Tona et al., 2007). Hatchability $(\mathrm{H})$ is told to be decreasing in parallel to decreasing $\mathrm{O}_{2}$ levels in air because of the increase in altitude and thus resulting in a worse $\mathrm{H}$ meaning a worse incubation performance and a worse chick quality which can certainly affect the growth performance as well. It has been reported that very poor results have been obtained in places such as South America and India with a high altitude $(3500-4000 \mathrm{~m})$ with $20.0 \% \mathrm{H}$ (Ahmed et al., 2013). To compensate this poor state, additional supplementary devices increasing the $\mathrm{O}_{2}$ levels in the machines are built. To increase the hatchability in high altitude areas, it is advised to increase the oxygen level of the air supplied to the machine as well as increasing the temperature (Christensen and Bagley, 1988). Increasing the $\mathrm{O}_{2}$ content of the air in the incubator from 21.5 to $23.4 \%$ (Sahan et al., 2006) especially at the eggs from the older flocks (Celen et al., 2009) is told to have improved $\mathrm{H}$. Whereas, there has been found different results about the effect of $\mathrm{CO}_{2}$ levels in the incubators on performance. There are several researchers implying that there has been either positive or negative effects of increasing $\mathrm{CO}_{2}$ levels to a specific maximum point or running $\mathrm{CO}_{2}$ control system of the machines (Onagbesan et al., 2008). In initial researches about the effects of $\mathrm{CO}_{2}$ levels during incubation (Romanoff, 1936) $\mathrm{CO}_{2}$ levels exceeding $1 \%$ during early stages resulted in poor hatchability $(\mathrm{H})$. Latter researches showed that increasing $\mathrm{CO}_{2}$ levels gradually to $1.50 \%$ from $1.00 \%$ which is normally the standard $\mathrm{CO}_{2}$ level of the first 10 days of incubation improved embryonic growth, early hatch and motivated $\mathrm{H}$ to increase (Tona et al., 2007). These effects were told to be differing between the races (De Smit et al., 2008; Tona et al., 2013). The high levels of $\mathrm{CO}_{2}$ after the first 10 days of incubation had changing effects on performance during and post incubation with the level the egss were exposed and the duration of the high level exposure (Everaert et al., 2007).

In the light of the studies mentioned, this research was conducted to evaluate the more detailed effects of machine ventilation programme, EST and in addition to this, the egg position in the incubator on embryo deaths and HFE and also to contribute to further researches which will be done on the same point or similar topics.

\section{Material and Method}

The animal material of the research, 1920 ROSS 308 broiler hatching eggs were obtained from a single 33 weeks old breeder flock of a commercial broiler production company located in Bolu province, by collecting the eggs at the same day and at the same time. Non-hatching eggs were sorted and were taken out of the research material. Later, all the eggs were numbered and were weighed $( \pm 1 \mathrm{mg})$ by a precision scale (Densi HZY2200B, Densi Ltd. Co., Turkey) and the data were recorded individually. The incubation period of the research took place in Abant Izzet Baysal University Faculty of Agriculture and Natural Sciences, Poultry Science Department's Incubation Laboratory at the 4 identical incubators with a capacity of 480 broiler 
hatching eggs (Cimuka 960SH, Cimuka Ltd. Co., Turkey).

The hatching eggs were sorted in 3 groups after weighing as, heavy $(65.55 \pm 0.08 \mathrm{~g})$, medium $(61.47 \pm 0.04 \mathrm{~g})$ and light $(57.56 \pm 0.08 \mathrm{~g})$. The eggs were sorted by weight and eggs of every weight group were set in all parts of every tray and also all incubator trays homogeneously to eliminate the effect of EW between the trays. So, same amount of eggs of every weight group and every treatment was represented in each tray by setting the eggs in certain locations (Table 1).

At the time of setting, to determine differences between egg (location) positions (EP) the eggs were set in defined orders. 40 of the 80 egg capacity trays were set on the side of the heater denominated as the heater side $(\mathrm{H})$ and the other 40 were set on the side of the door denominated as the door side (D). Similarly, 40 eggs on the side of the humidifier were named as the humidifier side $(\mathrm{Hu})$ and 40 eggs on the opposite side were named as the panel side (P). Besides, every trolley with 6 incubation trays were divided into 3 groups, the top 2 trays were named as top, middle 2 trays were named as middle and the bottom 2 trays were named as bottom. Every tray was considered as a replicate in a treatment (Table 1).

The eggs set to the incubator trays were kept under $18^{\circ} \mathrm{C}$ and $75 \%$ relative humidity for 2 days and intensive care was taken to keep the storage conditions stable during the storage period. After storage period, the trolleys which were formerly set with hatching eggs to obtain each treatment on every tray with equal number of eggs representing each treatment in every tray and every position were placed in the 4 identical incubators. Before the incubation period, the eggs were pre-heated in the incubators for 6 hours at $24^{\circ} \mathrm{C}$.

During the incubation period heating programmes of the incubators were arranged to obtain specific EST where EST at incubators 1 and 2 were kept at $37.78^{\circ} \mathrm{C}$ $\left(100.0^{\circ} \mathrm{F}\right)$ and EST at incubator 3 and 4 were kept at $38.06^{\circ} \mathrm{C} \quad\left(100.5^{\circ} \mathrm{F}\right)$. Besides, different ventilation programmes were applied to the 2 incubators which worked with the same EST values. These incubator ventilation programmes (IVP) were named as classic (C) and new (N). In the Classic (C) IVP there has been no manipulation on $\mathrm{CO}_{2}$ system of the incubators and at the remaining 2 incubators, in which New IVP was applied, every air inlets of the incubators were closed during the first 10 days of incubation and $\mathrm{CO}_{2}$ was allowed to increase. Later, air inlets of these 2 machines were opened and normal (Classic) IVP was conducted till the end of hatch. Relative humidity was kept around $57 \%$ in all incubators during the first 18 days of incubation period and egg turning was done hourly (24 times/day).

The $\mathrm{O}_{2}$ levels inside the incubator were measured and recorded by specific $\mathrm{O}_{2}$ data loggers (PAC 7000, Dragger Safety AG\&Co. KGaA, Germany) and $\mathrm{CO}_{2}$ levels were measured and recorded by $\mathrm{CO}_{2}$ sensors (Hatch Eco2-01, Cimuka Ltd. Co., Turkey) keeping the graphical data incubation long and in machine temperatures and humidity values were measured with temperaturehumidity sensors (KPL215, Galtech+Mela $\mathrm{GmbH}$, Germany) and also circulating air temperature inside the machine (CATI) and humidity values were measured and recorded by specific data loggers (Testo 175H1, Testo SE\&Co. KGaA, Germany) periodically. All measurements were double checked by separate data loggers and recorded. EST values were measured by an infrared ear thermometer (Braun Thermoscan, Braun, Germany) periodically and were recorded. EST values were of 24 eggs from each incubator were measured periodically from every treatment group on each tray and recorded. Right after the measurements were taken, mean EST values were calculated and alterations on incubators were done if necessary because of any deviation from the target EST values were observed.

At the 18. day of incubation, eggs were transferred from trays to hatching baskets of the same incubators without any change in the location of the eggs in relation to the EP. Right after take-off (end of incubation) unhatched eggs were broken, fertility and the incidences of embryonic deaths were determined and recorded as early stage (0-5 days) embryo deaths (ED), mid-stage (617 days) embryo deaths (MD) and lastly late stage (18-21 days) embryo deaths and pipped but unhatched chick (LD+PBU) percentages. From these data collected, embryonic death rates and hatchability of fertile eggs (HFE) ratios were calculated.

Table 1 The egg weight values obtained from the treatment groups of the research.

\begin{tabular}{|c|c|}
\hline & EW, g \\
\hline \multicolumn{2}{|l|}{ Generally } \\
\hline $\mathrm{C}, 37.78^{\circ} \mathrm{C} \mathrm{EST}$ & $61.88 \pm 0.16$ \\
\hline $\mathrm{N}, 37.78^{\circ} \mathrm{C} \mathrm{EST}$ & $61.53 \pm 0.17$ \\
\hline $\mathrm{C}, 38.06^{\circ} \mathrm{C} \mathrm{EST}$ & $61.42 \pm 0.16$ \\
\hline $\mathrm{N}, 38.06^{\circ} \mathrm{C} \mathrm{EST}$ & $61.50 \pm 0.16$ \\
\hline \multicolumn{2}{|l|}{ IVP } \\
\hline Classic & $61.48 \pm 0.31$ \\
\hline New & $61.49 \pm 0.32$ \\
\hline \multicolumn{2}{|l|}{$\mathrm{EST},{ }^{\circ} \mathrm{C}$} \\
\hline 37.78 & $61.69 \pm 0.34$ \\
\hline 38.06 & $61.28 \pm 0.29$ \\
\hline \multicolumn{2}{|l|}{ EW, g } \\
\hline Heavy & $65.52 \pm 0.08^{\mathrm{a}}$ \\
\hline Medium & $61.47 \pm 0.04^{b}$ \\
\hline Light & $57.56 \pm 0.08^{c}$ \\
\hline \multicolumn{2}{|l|}{ EP } \\
\hline Heater & $61.69 \pm 0.17$ \\
\hline Door & $61.51 \pm 0.17$ \\
\hline Humidifier & $61.67 \pm 0.17$ \\
\hline Wall & $61.54 \pm 0.17$ \\
\hline Top & $61.67 \pm 0.14$ \\
\hline Middle & $61.48 \pm 0.14$ \\
\hline Bottom & $61.59 \pm 0.14$ \\
\hline \multicolumn{2}{|l|}{$\mathrm{P}$ value } \\
\hline General & 0,206 \\
\hline $\mathrm{EW}$ & 0.000 \\
\hline IVP & 0,990 \\
\hline EST & 0,352 \\
\hline EP & 0,939 \\
\hline
\end{tabular}

${ }^{a b}$ Different superscript letters show that difference between means of groups are statistically important $(\mathrm{P}<0.05)$. EST: Egg Shell Temperature, EW: Egg Weight, EP: Egg Position, IVP: Incubator Ventilation Programme, N: New C: Classic. 
Effects of egg weight (EW), egg position (EP), egg shell temperature (EST) and incubator ventilation program (IVP) on embryo mortality (EM), hatchability of fertile eggs (HFE) in broiler breeder hatching eggs were analyzed to following model.

$$
\mathrm{Y}_{\mathrm{ijk}}=\mu+\mathrm{a}_{\mathrm{i}}+\mathrm{b}_{\mathrm{j}}+\mathrm{c}_{\mathrm{k}}+\mathrm{d}_{\mathrm{l}}+\mathrm{e}_{\mathrm{ijk} \mathrm{l}}
$$

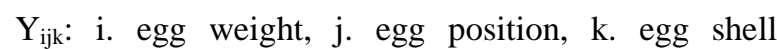
temperature, 1. incubator ventilation program, m. tray's ED, MD, LD+PBU rates, HFE. $\mu$ : general mean $a_{i}$ : effect of egg weight $(i=1,2,3) . b_{j}$ : effect of egg position $(j=1,2,3,45,6,7)$. $c_{k}$ : effect of egg shell temperature $(\mathrm{k}=1,2) . \quad \mathrm{d}_{\mathrm{l}}$ : effect of incubator ventilation program $(l=1,2), \mathrm{e}_{\mathrm{ijkl}}$ : randomly error.

The research was conducted in randomized plot design. Analyses were done by (ANOVA) one way analyses of variance and (GLM) general linear model by computer with the SPSS 22 (SPSS, 2013) statistical software. The tests of difference between the groups were analysed by Tukey test. All parameters of the experiment were given as Mean \pm Standard Error of the Mean $(\mathrm{M} \pm \mathrm{SEM})$.

The research was approved by the Abant Izzet Baysal University Ethical Board of Experimental Animals (Verdict No: 2015/45, 16.12.2015), funded by Research Projects Committee (Project No. 2016.10.03.990, 12.01.2016) and was conducted in coherence to the project.

\section{Results}

In the first stage of the research, the hatching eggs used were set to the trays according to the trial tray design the egg weights (EW) were investigated (Table 1). The difference between the treatment groups of EW (heavy, light and medium) were found to be statistically important $(\mathrm{P}=0.000)$.
From the trial, when the EST data obtained from the EP about the treatment groups were examined, the temperature difference between top and bottom trays were found to be up to $0.57^{\circ} \mathrm{C}$ (Table 2).

EST, CATI and MT data were also investigated obtained from the experiment. EST values were found to be higher than MT and CATI values where the difference was found to be $0.1-2.1^{\circ} \mathrm{C}$ (Table 3 ).

The $\mathrm{CO}_{2}$ and $\mathrm{O}_{2}$ data which were measured and recorded by sensors and data loggers inside the incubator were investigated from the IVP treatment groups. By the result of keeping the air inlets of the New IVP applied incubators closed for the first 10 days of incubation it has been observed that the $\mathrm{CO}_{2}$ levels inside the machine went up to $1.50 \%$ gradually and the difference between the new $(\mathrm{N})$ and classic $(\mathrm{C})$ group has risen up to $0.9 \%$ levels. $\mathrm{O}_{2}$ levels decreased in parallel to the ascension of the $\mathrm{CO}_{2}$ levels in the incubators gradually to $20.25 \%$ and the difference between $\mathrm{O}_{2}$ levels of New and Classic IVP groups raised up to $0.12 \%$ (Table 4 ).

The $\mathrm{CO}_{2}$ and $\mathrm{O}_{2}$ data obtained from the machine during the whole incubation period were analysed and $\mathrm{CO}_{2}$ levels gradually increased from $0.40 \%$ at the beginning of incubation to $1.30 \%$ at the end of the incubation period, whereas, the $\mathrm{O}_{2}$ levels declined gradually from $20.90 \%$ to $20.30 \%$ till the end of the incubation period (Table 4).

From the data obtained, to identify the effects of the treatments EW, EST, IVP and EP on hatch results EM (embryo mortality) and HFE data were analysed (Table 5).

From the EW treatment, some numerically differences have been found in some EM and HFE data and the differences on HFE data showed more distinction. Therewithal, less last stage and pipped but not hatched chicks (LS+PBU) rates have been found in lighter eggs then light eggs $(\mathrm{P}<0.05)$ and conclusively, higher HFE rates have been found in this group $(\mathrm{P}<0.05)$.

Table 2 Egg shell temperature values obtained from the treatment groups of the research.

\begin{tabular}{l|cccc}
\hline \multirow{2}{*}{\multicolumn{1}{c|}{}} & \multicolumn{2}{c}{ EST, ${ }^{\circ} \mathrm{C}$} & IVP & C \\
\cline { 2 - 5 } EP & 37.78 & 38.06 & $38.17 \pm 0.04$ \\
Top & $38.05 \pm 0.05$ & $38.31 \pm 0.05$ & $38.19 \pm 0.05$ & $38.17 \pm 0.04$ \\
Middle & $37.75 \pm 0.04$ & $38.07 \pm 0.04$ & $37.91 \pm 0.05$ & $37.91 \pm 0.04$ \\
Bottom & $37.47 \pm 0.04$ & $37.73 \pm 0.05$ & $37.60 \pm 0.05$ & $37.61 \pm 0.06$ \\
\hline \multicolumn{7}{c}{ Temperature Differences } & $0.30 \pm 0.04$ & $0.24 \pm 0.02$ & $0.28 \pm 0.02$ & $0.26 \pm 0.03$ \\
\hline Top - Middle & $0.57 \pm 0.07$ & $0.56 \pm 0.05$ & $0.55 \pm 0.08$ & $0.57 \pm 0.06$ \\
Top - Bottom & $0.31 \pm 0.06$ & $0.32 \pm 0.05$ & $0.30 \pm 0.07$ & $0.33 \pm 0.07$ \\
Middle - Bottom &
\end{tabular}

EST: Egg Shell Temperature, EP: Egg Position, IVP: Incubator Ventilation Programme, N: New Incubator Ventilation Program C: Classic Incubator Ventilation Program.

Table 3 Egg shell temperature, machine temperature and circulating air temperature inside the machine values obtained from the research.

\begin{tabular}{l|cccccc}
\hline \multirow{2}{*}{ Treatment } & \multicolumn{3}{|c}{ Temperatures, ${ }^{\circ} \mathrm{C}$} & \multicolumn{3}{c}{ Difference, ${ }^{\circ} \mathrm{C}$} \\
\cline { 2 - 7 } & EST & MT & CATI & EST-CATI & EST-MT & MT-CATI \\
\hline $37.78^{\circ} \mathrm{C} \mathrm{EST}$ & $37.78 \pm 0.01$ & $35.88 \pm 0.28$ & $35.79 \pm 0.08$ & $1.90 \pm 0.27$ & $1.99 \pm 0.08$ & $0.09 \pm 0.21$ \\
$38.06^{\circ} \mathrm{C} \mathrm{EST}$ & $38.06 \pm 0.02$ & $36.36 \pm 0.22$ & $36.60 \pm 0.11$ & $1.70 \pm 0.21$ & $1.45 \pm 0.11$ & $-0.25 \pm 0.12$ \\
IVP C & $37.92 \pm 0.02$ & $35.77 \pm 0.23$ & $36.13 \pm 0.09$ & $2.14 \pm 0.23$ & $1.79 \pm 0.09$ & $-0.36 \pm 0.16$ \\
IVP N & $37.92 \pm 0.02$ & $36.46 \pm 0.26$ & $36.26 \pm 0.10$ & $1.46 \pm 0.25$ & $1.66 \pm 0.94$ & $0.20 \pm 0.16$ \\
\hline
\end{tabular}

EST: Egg Shell Temperature, MT: Machine Temperature, CATI: Circulating Air Temperature inside the Machine, IVP: Incubator Ventilation Programme, C: Classic, N: New. 
Table 4 The $\mathrm{CO}_{2}$ and $\mathrm{O}_{2}$ data during the whole incubation period of the trial about IVP.

\begin{tabular}{c|cccccc}
\hline Day & $\mathrm{C} \mathrm{CO}_{2} \%$ & $\mathrm{~N} \mathrm{CO}_{2} \%$ & $\mathrm{CO}_{2}$, Difference & $\mathrm{C} \mathrm{O}_{2}, \%$ & $\mathrm{~N} \mathrm{O}_{2}, \%$ & $\mathrm{O}_{2}$, Difference \\
\hline 0 & 0.40 & 0.40 & 0.00 & 20.90 & 20.87 & 0.03 \\
1 & 0.42 & 0.47 & -0.05 & 20.90 & 20.87 & 0.03 \\
2 & 0.46 & 0.58 & -0.12 & 20.90 & 20.87 & 0.03 \\
3 & 0.43 & 0.70 & -0.27 & 20.90 & 20.90 & 0.00 \\
4 & 0.47 & 0.81 & -0.34 & 20.90 & 20.90 & 0.00 \\
5 & 0.54 & 0.83 & -0.29 & 20.86 & 20.84 & 0.02 \\
6 & 0.58 & 0.94 & -0.36 & 20.78 & 20.75 & 0.03 \\
7 & 0.55 & 1.08 & -0.54 & 20.43 & 20.39 & 0.03 \\
8 & 0.59 & 1.22 & -0.63 & 20.40 & 20.33 & 0.07 \\
9 & 0.56 & 1.39 & -0.83 & 20.40 & 20.31 & 0.09 \\
10 & 0.60 & 1.50 & -0.90 & 20.37 & 20.25 & 0.12 \\
11 & 0.70 & 1.20 & -0.50 & 20.34 & 20.34 & 0.00 \\
12 & 0.68 & 0.95 & -0.27 & 20.31 & 20.32 & -0.01 \\
13 & 0.76 & 0.80 & -0.04 & 20.31 & 20.35 & -0.04 \\
14 & 0.84 & 0.90 & -0.06 & 20.30 & 20.35 & -0.05 \\
15 & 0.82 & 0.90 & -0.08 & 20.30 & 20.35 & -0.05 \\
16 & 0.90 & 0.95 & -0.05 & 20.34 & 20.35 & -0.00 \\
17 & 0.88 & 0.85 & 0.03 & 20.34 & 20.35 & -0.01 \\
18 & 0.96 & 0.85 & 0.11 & 20.31 & 20.35 & -0.04 \\
19 & 1.04 & 0.85 & 0.19 & 20.32 & 20.34 & 0.02 \\
20 & 1.12 & 1.00 & 0.12 & 20.28 & 20.27 & 0.01 \\
\hline 1VP & 1.10 & 1.30 & -0.20 & 20.29 & 20.29 & 0.00 \\
\hline
\end{tabular}

IVP: Incubator Ventilation Programme, C: Classic, N: New.

Table 5 The effects of egg shell temperature, egg weight, incubator ventilation programme and egg position on embryo mortality and hatchability of fertile eggs.

\begin{tabular}{|c|c|c|c|c|}
\hline & \multicolumn{3}{|c|}{ Embryo Mortality, \% } & \multirow[b]{2}{*}{ HFE } \\
\hline & $\begin{array}{c}\text { Early Stage } \\
0-5 \text { day }\end{array}$ & $\begin{array}{c}\text { Mid-Stage } \\
\text { 6-17 day }\end{array}$ & $\begin{array}{l}\text { Last Stage+Pipped } \\
\text { But Not Hatched }\end{array}$ & \\
\hline \multicolumn{5}{|l|}{ General } \\
\hline $\mathrm{C}, 37.78^{\circ} \mathrm{C} \mathrm{EST}$ & $1.04 \pm 0.37$ & $0.42 \pm 0.28$ & $4.79 \pm 1.09$ & $93.75 \pm 0.84$ \\
\hline $\mathrm{N}, 37.78^{\circ} \mathrm{C} \mathrm{EST}$ & $1.25 \pm 0.58$ & $1.25 \pm 0.84$ & $5.42 \pm 0.92$ & $92.08 \pm 1.44$ \\
\hline $\mathrm{C}, 38.06^{\circ} \mathrm{C} \mathrm{EST}$ & $1.88 \pm 0.88$ & $1.04 \pm 0.37$ & $6.67 \pm 1.08$ & $90.42 \pm 0.74$ \\
\hline $\mathrm{N}, 38.06^{\circ} \mathrm{C} \mathrm{EST}$ & $1.25 \pm 0.49$ & $0.63 \pm 0.33$ & $9.17 \pm 1.69$ & $88.96 \pm 1.86$ \\
\hline \multicolumn{5}{|l|}{ IVP } \\
\hline Classic $(\mathrm{C})$ & $1.15 \pm 0.30$ & $0.52 \pm 0.21$ & $6.98 \pm 1.08$ & $91.35 \pm 1.12$ \\
\hline $\operatorname{New}(\mathrm{N})$ & $1.25 \pm 0.37$ & $0.94 \pm 0.45$ & $7.29 \pm 1.02$ & $90.52 \pm 1.19$ \\
\hline \multicolumn{5}{|l|}{$\mathrm{EST},{ }^{\circ} \mathrm{C}$} \\
\hline 37.78 & $1.15 \pm 0.34$ & $0.83 \pm 0.44$ & $5.10 \pm 0.70^{\mathrm{b}}$ & $92.92 \pm 0.83^{\mathrm{a}}$ \\
\hline 38.06 & $1.56 \pm 0.50$ & $0.83 \pm 0.25$ & $8.85 \pm 1.13^{\mathrm{a}}$ & $89.69 \pm 0.99^{\mathrm{b}}$ \\
\hline \multicolumn{5}{|l|}{ EW, g } \\
\hline Heavy $(65.55 \pm 0.21)$ & $0.79 \pm 0.40$ & $0.48 \pm 0.48$ & $9.54 \pm 1.39^{\mathrm{a}}$ & $89.03 \pm 1.42^{\mathrm{b}}$ \\
\hline Medium $(61.64 \pm 0.09)$ & $2.02 \pm 0.68$ & $0.31 \pm 0.21$ & $7.02 \pm 0.93^{\mathrm{ab}}$ & $91.27 \pm 1.16^{\mathrm{ab}}$ \\
\hline Light $(57.51 \pm 0.21)$ & $1.87 \pm 0.67$ & $1.25 \pm 0.43$ & $3.92 \pm 0.74^{\mathrm{b}}$ & $93.58 \pm 0.93^{\mathrm{a}}$ \\
\hline \multicolumn{5}{|l|}{ EP } \\
\hline Heater & $1.15 \pm 0.34$ & $0.52 \pm 0.21$ & $7.29 \pm 0.97$ & $91.04 \pm 1.07$ \\
\hline Door & $1.25 \pm 0.34$ & $0.83 \pm 0.36$ & $6.35 \pm 0.88$ & $91.56 \pm 1.08$ \\
\hline Humidifier & $0.94 \pm 1.77$ & $0.73 \pm 0.24$ & $6.98 \pm 1.13$ & $91.67 \pm 0.98$ \\
\hline Panel & $1.77 \pm 0.51$ & $0.94 \pm 0.45$ & $6.98 \pm 0.89$ & $90.94 \pm 0.96$ \\
\hline Top & $1.41 \pm 0.46$ & $0.47 \pm 0.25$ & $5.63 \pm 0.84$ & $92.03 \pm 0.86$ \\
\hline Middle & $1.41 \pm 0.25$ & $0.78 \pm 0.30$ & $10.00 \pm 1.53$ & $89.53 \pm 1.41$ \\
\hline Bottom & $1.25 \pm 0.40$ & $1.25 \pm 0.65$ & $5.31 \pm 0.88$ & $92.34 \pm 1.15$ \\
\hline \multicolumn{5}{|l|}{$\mathrm{P}$ number } \\
\hline General & 0.787 & 0.644 & 0.061 & 0.069 \\
\hline IVP & 0.828 & 0.404 & 0.835 & 0.613 \\
\hline EST & 0.489 & 1.000 & 0.007 & 0.030 \\
\hline EW & 0.287 & 0.205 & 0.002 & 0.016 \\
\hline $\mathrm{EP}$ & 0.864 & 0.841 & 0.112 & 0.736 \\
\hline
\end{tabular}

EST: Egg Shell Temperature, EW: Egg Weight, IVP: Incubator Ventilation Programme, C: Classic, N: New, EP: Egg Position, HFE: Hatchability of Fertile Eggs, \%, abc Different superscript letters show that difference between means of groups are statistically important $(\mathrm{P}<0.05)$. 
Similarly, when EST treatment group data was analysed, the differences in LS+PBU and HFE data were found to be statistically important between the groups $(\mathrm{P}<0.05)$. There has been found higher $\mathrm{LS}+\mathrm{PBU}$ in $38.06^{\circ} \mathrm{C}$ EST groups so lower HFE has been found withal $(\mathrm{P}<0.00)$.

There has been found some numerical differentiation between the EP treatment groups. Especially, the differences between treatment groups about LS+PBU and HFE data seemed to be visible where the variation between the groups was found not to be important statistically $(\mathrm{P}>0.05)$.

When the data about IVP were inspected, numerical differences were found about the treatment groups of EM and HFE data where those variances were also found not to be statistically important $(\mathrm{P}>0.05)$. Therewithal, the differences between classic and new IVP treatment groups about the EM and HFE data were found not to be statistically important $(\mathrm{P}>0.05)$.

\section{Discussion and Conclusion}

In this experiment, the effects of EW, EST, IVP and EP on EM and HFE of broiler eggs from middle aged breeders were investigated.

From the EW treatment of the experiment, in light eggs there has been found less LS+PBU and withal higher HFE data were found $(\mathrm{P}<0.05)$. The data acquired from the research is in line with some researches showing that HFE is decreasing when EW increases (Huwaida et al., 2015) and most of the EMs causing this situation are early stage (Rosa et al., 2002; Abiola et al., 2008) and early and late stage EMs together (Elibol and Brake, 2008).

In the EST treatment, there has been found last stage + pipped but not hatched EMs and higher HFE values in the $37.78^{\circ} \mathrm{C}$ of the high EST (HST) group ED $(\mathrm{P}<0.05)$. Those findings stated out that with a difference of $0.28^{\circ} \mathrm{C}$ $\left(0.5^{\circ} \mathrm{F}\right) \operatorname{EST}\left(37.78^{\circ} \mathrm{C}\right.$ rather than $\left.38.06^{\circ} \mathrm{C}\right)$ treatment changes EM and HFE data. The collected data were parallel with the EST researches advising that EST should be between $37-38^{\circ} \mathrm{C}$ (Decuypere et al., 2001; Lourens et al., 2005; Joseph et al., 2006; Hulet et al., 2007; Saito and Kita, 2011) and the highest performance was told to be acquired in $37.78^{\circ} \mathrm{C}$ EST group (Lourens et al., 2005; Joseph et al. 2006).

When the effect of EP on EM and HFE results was analysed, there has been numerically difference between treatment groups but these differences were found to be statistically not important $(\mathrm{P}>0.05)$.

The data about EST, CATI and MT differences in relation to $\mathrm{EP}, \mathrm{EW}$ and embryonic age obtained from the research is in line with other research reporting that these differences are changing between $0.4^{\circ} \mathrm{C}$ and $4.0^{\circ} \mathrm{C}$ (Lourens and Middelkoop 2000; Joseph et al., 2006; Elibol and Brake 2008). However, these research findings are not in harmony with the results of other researches expressing that it is probable that the circulating air speed inside the machine is getting slower through the eggs set far away from the circulation fan affecting heavier eggs more therefore last stage EDs are told to be more decreasing the HFE (Elibol and Brake 2008). This situation is thought to be arising from CATI differences, which is told to be affecting EM and HFE significantly when less than $4^{\circ} \mathrm{C}$ and precisely occurred as $0.1-2.1^{\circ} \mathrm{C}$ in the experiment.

Also, when the treatments are arranged as 37.78 $38.06^{\circ} \mathrm{C}$ EST levels at the eggs collected from middle aged breeders, it has been found that EP, was not affected significantly EM and hence HFE ( $\mathrm{P}>0.05)$.

When the data of the treatment groups about IVP were analysed, some non-distinctive numerical differences were found between data of the groups in relation to EM and HFE. Consequently, the differences between the data of the new and classic IVP groups in relation to EM and HFE were found not to be statistically important $(\mathrm{P}>0.05)$. As a result, the $\mathrm{CO} 2$ levels which gradually increases during the first 10 days of incubation up to $1.5 \%$ was found not to be effecting EM and HFE statistically (P>0.05).

The findings acquired from the experiment is not in line with the experiment conducted by the researchers stating that during the first 10 days of incubation the gradually increasing $\mathrm{CO}_{2}$ levels from normally $1 \%$ to $1.5 \%$ enhanced embryonic growth, encouraged early hatchability in turkey and chicken eggs so increased total hatchability (Tona et al., 2007). Alike, the findings of the research is inharmonious with the outcome of another experiment stating that early stage deaths are triggered and hatchability decreases by $\mathrm{CO}_{2}$ levels exceeding $1 \%$ (Romanoff, 1936). This situation is thought to be arising from the evolution of the incubation technology and the progress of the overall poultry sector during the last decades.

Evaluating the total outcome of the experiment, egg weight and egg shell temperature were found to be affecting last stage + pipped but unhatched embryo deaths and as a result hatchability of fertile eggs. Consequently, for achieving less embryo mortality and in this connection higher hatchability of fertile eggs and conclusively higher incubation performance, besides egg weight, egg shell temperatures should be taken into consideration wisely.

\section{References}

Abiola SS, Meshioye OO, Oyerinde BO,Bamgbose MA. 2008. Effect of egg size on hatchability of broiler chicks. Arc. Zootec. 57: 83-86. http://www.uco.es/organiza/servicios/ publica/az/php/img/web/07_10_06_12NotaEffectAbiola.pdf Ahmed M, Biswas A, Roy BG, Srivastava RB. 2013. Frequently encountered problems during hatching in cold arid high altitude regions such as Ladakh in India: causes and remedies. W. Poult. Sci. J. 69: 897-901. DOI: 10.1017/S0043933913000895.

Celen MF, Yildirim I, Parlat SS, Alkis E. 2009. The effects of broiler breeder age and extra oxygen addition into incubator at high altitude $(1700 \mathrm{~m})$ on hatching results and subsequent performance in broilers. J. of Ani. and Vet. Adv. 8(7): 14371442. ISSN: 1680-5593.

Christensen VL, Bagley LG. 1988. Improved hatchability of turkey eggs at high altitudes due to added oxygen and increased incubation temperature. Poult. Sci. 67: 956-960. PMID: 3413023.

Decuypere E, Tona K, Bruggeman V, Bamelis F. 2001. The day-old chick: a crucial hinge between breeders and broilers. W. Poult. Sci. J. 57: 127-138. DOI: 10.1079/WPS20010010. 
De Smit L, Bruggeman V, Debonne M, Tona JK, Kamers B, Everaert N, Witters A. 2008. The effect of nonventilation during early incubation on the embryonic development of chicks of two commercial broiler strains differing in ascites susceptibility. Poult. Sci. 87: 551-560. DOI: 10.3382/ps.2007-00322.

Elibol O, Brake, J. 2008. Effect of egg weight and position relative to incubator fan on broiler hatchability and chick quality. Poult. Sci. 87: 1913-1918. DOI: 0.3382/ps.200800014.

Elibol O, Turkoglu M. 2014. Embriyo development and incubation. In: Türkoğlu M and Sarıca M. (Ed.) 2014. Poutry Science (Bey Ofset, Ankara, Turkey): pp. 200-206. ISBN: 978-975-94647-2-1

Everaert N, Kamers B, Witters A, De Smit L, Debonne M, Decuypere E, Bruggeman V. 2007. Effect of four percent carbon dioxide during the second half of incubation on embryonic development, hatching parameters and posthatch growth. Poult. Sci. 86: 1372-1379. DOI: 10.1093/ps/86.7.1372. PMID: 17575184.

French NA. 1997. Modeling incubation temperature: the effects of incubator design, embryonic development, and egg size. Poult. Sci. 76: (1): 124-133. PMID: 9037699.

French NA. 2009. The critical importance of incubation temperature. Av1. B1o. Res. 2 (1/2): 55-59. DOI: 10.3184/175815509X431812.

Hulet R, Gladys G, Hill D, Meijerhoff R, El-Shiekh T. 2007. Influence of egg shell embriyonic incubation temperature and broiler breeder flock age on posthatch growth performance and carcass characteristics. Poult. Sci. 86: 408412. PMID: 17234858.

Huwaida EE, Sakin MAIY, Elagib HAA, Bakhiet E, Dousa BM, Elamin KM. 2015. Effect of egg weight and egg shell thickness on hatchability and embryonic mortality of cobb broiler breeder eggs. Global J. of Ani. Sci. Res. 3(1): 186190. ISSN: 2345-4377. http://www.gjasr.com/index.php /GJASR/article/viewFile/141/373

Joseph NS, Lourens A, Moran Jr ET. 2006. The effects of suboptimal eggshell temperature during incubation on broiler chick quality, live performance, and further processing yield. Poult. Sci. Vol 85: 932-938. PMID: 16673774.

Lourens A, Brand H, Meijherhof R, Kemp B. 2005. Effect of eggshell temperature during incubation on embryo development, hatchability, and posthatch development. Poultry Science 84; 914-920. PMID: 15971530.

Meijerhoff R. 2009. The influence of incubation on chick quality and broiler performance. $20^{\text {th }}$ Aust. Poult. Sci. Symp. New South Wales, Sdyney, Aust. 9-11 Feb. 2009. pp: 106111
Onagbesan O, Bruggeman V, De Smit L, Debonne M, Witters A, Tona K, Everaert N and Piestun Y, Shinder D, Ruzal M, Halevy O, Brake J, Yahav S. 2008. Thermal manipulations during broiler embryogenesis: effect on the acquisition of thermotolerance. Poult.y Sci. 87: 1516-1525. DOI: 10.3382/ps.2008-00030. PMID: 18648043.

Romanoff AL. 1936. Effects of different temperatures in the incubator on the prenatal and postnatal development of the chick. Poult. Sci. 15:311-315. DOI: 10.3382/ps.0150311.

Rosa PS, Guidoni AL, Lima IL, Bersch FXR. 2002. Effect of incubation temperature on hatching results of broiler breeders eggs classified by weight and hen age. Rev. Bras. de Zoot. 31: 1011-1016. DOI: 10.1590/S151635982002000400025.

Sahan U, Ipek A, Altan O, Yilmaz Diken B. 2006. Effects of oxygen supplementation during the last stage of incubation on broiler performance, ascites susceptibility and some physiological traits. Ani. Res. 55(2) 145-152. DOI: 10.1051/animres:2006003.

Saito F, Kita K. 2011. Maternal intake of astaxanthin improved hatchability of fertilized eggs stored at high temperature. J. of Poult. Sci. 48: 33-39. DOI: 10.2141/jpsa.010090.

Shim MY, Pesti GM. 2011. Effects of incubation temperature on the bone development of broilers. Poult. Sci. Vol 90: 18671877. DOI: $10.3382 /$ ps.2010-01242.

SPSS. 2013. SPSS Release 22.0 Statistical packet program, SPSS for Windows. SPSS Inc., Chicago, IL. USA.

Tona K, Onagbesan Otona, Bruggeman V, De Smit L, Figueiredo D, Decuypere E. 2007. Non-ventilation during early incubation in combination with dexamethasone administration during late incubation. 1. Effects on physiological hormone levels, incubation duration and hatching events. Dom. Anim. Endoc. 33(1): 32-46. DOI: 10.1016/j.domaniend.2006.04.002. PMID: 16697137.

Tona K, Everaert N, Willemsen H, Gbeassor M, Decuypere E, Buyse J. 2013. Effects of interaction of incubator $\mathrm{CO}_{2}$ levels and mixing hatching eggs of different embryo growth trajectory on embryo physiological and hatching parameters. Brit. Poult. Sci. 54 (4): 545-551. DOI: 10.1080/00071668. 2013.807907.

Turkoglu M, Sarica M. 2014. Poultry breeder husbandry. In: Türkoğlu M and Sarıca M. (Ed.) 2014. Poutry Science (Bey Ofset, Ankara, Turkey): p. 344-350. ISBN: 978-975-94647$2-1$

Walter I, Seebacher F. 2009. Endothermy in birds: underlying molecular mechanisms. The J. of Exp. Bio. 212: 2328-2336. DOI: 10.1242/jeb.029009. PMID: 19617425. 